medRxiv preprint doi: https://doi.org/10.1101/2021.04.28.21255760; this version posted September 22, 2021. The copyright holder for this preprint (which was not certified by peer review) is the author/funder, who has granted medRxiv a license to display the preprint in

All rights reserved. No reuse allowed without permission.

\title{
SARS-CoV-2 infections in airway epithelial cells from smokers versus non-smokers
}

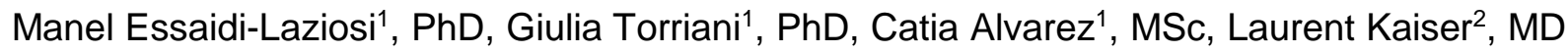
and Isabella Eckerle ${ }^{1,2}, \mathrm{MD}$.

'Department of Microbiology and Molecular Medicine, University of Geneva, Geneva, Switzerland

${ }^{2}$ Geneva Centre for Emerging Viral Diseases, Geneva University Hospitals, Geneva, Switzerland.

*Corresponding author: Isabella Eckerle, Geneva Centre for Emerging Viral Diseases, Geneva University Hospitals, Geneva, Switzerland.Geneva University Hospitals, Rue Gabrielle-Perret-Gentil 4, 1205 Geneva, Switzerland. Tel: +41223729820; FAX: +41223724097; Email: isabella.eckerle@unige.ch

\section{Summary}

Whether smoking exacerbates Coronavirus disease 2019 is still debated. Ex-vivo Infection of reconstituted epithelial tissues from smoker versus non-smoker donors suggested comparable susceptibility to SARS-CoV-2 in epithelia from both groups.

\section{Key words}

SARS-CoV-2, smokers, airway epithelia, ALI culture, host response and virus replication

\section{Abbreviations}

SARS-CoV-2: Severe Acute Respiratory Syndrome Coronavirus 2; COVID119: coronavirus disease 2019; URT/LRT: upper/lower respiratory tract; AECs: airway epithelial cells; ALI: airliquid interface; MOI: multiplicity of infection. ACE-2: Angiotensin Converting Enzyme II and IFN: Interferon. 
medRxiv preprint doi: https://doi.org/10.1101/2021.04.28.21255760; this version posted September 22, 2021. The copyright holder for this preprint (which was not certified by peer review) is the author/funder, who has granted medRxiv a license to display the preprint in All rights reserved. No reuse allowed without permission.

Controversial conclusions have been drawn from epidemiological studies reporting both an increased and decreased risk of both Severe Acute Respiratory Syndrome Coronavirus 2 (SARS-CoV-2) infection and Coronavirus disease 2019 (COVID-19) exacerbation for smokers [1]. Although a synopsis of available evidence suggests that current smoking is associated with an increased disease severity and death rate in hospitalized COVID-19 patients [2], further investigations are still needed. Also, cumulative smoking exposure was recently reported as an independent risk factor for hospitalization and death due to COVID19 [3]. Pathophysiological mechanisms involved in a higher susceptibility to infection or disease could be multifactorial, as it is known that smoking leads to altered expression of inflammatory cytokines and impaired innate immunity in the mucosa, increased permeability of epithelial cells and impaired mucociliary clearance function, as well as epigenetic modifications within the epithelium of the respiratory tract. In particular, overexpression of Angiotensin Converting Enzyme II (ACE-2) in the respiratory tract, leading to more efficient entry of SARS-CoV-2 into cells, was hypothesized to increase risk of SARS-CoV-2 infection and COVID-19 [4-6].

In vitro reconstituted human primary airway epithelial cells constitute an appropriate surrogate model for studying the first steps of respiratory viral infections, closely mimicking the in vivo situation [7]. Such primary cells are available from healthy donors, but also from patients with pre-existing respiratory disorders, including cystic fibrosis, chronic obstructive pulmonary disease, asthma and also from individuals with a history of smoking.

In our study, we have investigated SARS-CoV-2 replication in reconstituted upper respiratory tract (URT) airway epithelial cells (AECs) derived from the bronchial epithelium from individuals with ( $n=3,25$ to 80 pack years), or without ( $n=3$, no other pathologies) a history of smoking (Table 1). All epithelial tissues originating from smokers and non-smokers donors have been purchased from Epthelix SARL(https://www.epithelix.com/). Their production was conducted according to the Declaration of Helsinki on biomedical research (Hong Kong amendment, 1989), and the research protocol was approved by the local ethics committee. 
medRxiv preprint doi: https://doi.org/10.1101/2021.04.28.21255760; this version posted September 22, 2021. The copyright holder for this preprint (which was not certified by peer review) is the author/funder, who has granted medRxiv a license to display the preprint in All rights reserved. No reuse allowed without permission.

To better recapitulate the in vivo situation, infections were performed in air-liquid interface (ALI) system, as previously described [8], and a SARS-CoV-2 stock was obtained from a clinical isolate collected during the first pandemic wave in March 2020 on AECs, to avoid any adaptation to cell culture during the isolation process (initial sequence registered at GISAID hCoV-19/Switzerland/GE-SNRCI-29943121/2020|EPI_ISL_414019|2020-02-27). Sequencing the initial patient specimen and the isolate did not reveal any mutations. Infection assays were performed at $37^{\circ} \mathrm{C}$ and a multiplicity of infection (MOI) of 0.01 . Viral replication was assessed by quantitative real time PCR (RT-qPCR) from RNA extracted from apical tissue washes collected at days 2 and 4 post-infection (dpi). Compared to 3 hours post infection, SARS-CoV2 replication was equally efficient at 2 (2.07E10, SD $\pm 3.9 \mathrm{E} 10 \mathrm{SARS}-\mathrm{CoV}-2 \mathrm{RNA}$ copies/mL) and $4 \mathrm{dpi}(1.26 \mathrm{E} 11 \mathrm{SD} \pm 1.82 \mathrm{E}+11 \mathrm{SARS}-\mathrm{CoV}-2 \mathrm{RNA}$ copies $/ \mathrm{mL})$ in tissues from both smokers and non-smokers (Figure 1A). At day 4 post infection, interferon and ACE-2 inductions were determined by RT-qPCR from total RNA extracted from the cell lysates and represented as the fold change relative to non-infected tissues (figure 2). As expected [8], type III IFN induction in infected tissues (10E4 fold increase) is higher than type I (Figure 1B). Comparing smokers and non-smokers, similar expression levels of IFNs $\alpha, \beta$ and $\lambda$ and ACE-2 were also observed in mock- (data not shown) and SARS-CoV-2-infected tissues at $4 \mathrm{dpi}$ (Figure 1B). Altogether, our data showed similar ex vivo viral replication and host-response in SARS-CoV-2-infected tissues of the upper respiratory tract from smokers versus non-smoker donors, indicating comparable susceptibility to SARS-CoV-2 in bronchial epithelia from both groups.

Although several studies have found an influence of smoking on increased ACE-2 expression mainly in the lower respiratory tract (LRT), with potentially higher susceptibility to, and increased replication of, SARS-CoV-2; no such effect was observed in our model on AECs from the URT, the primary entry site of SARS-CoV-2 [9].

In our highly relevant ex vivo model derived from the airway epithelium, similar susceptibility to viral infection and replication, as well as comparable host profiles, in both groups were observed. Thus ACE-2 expression, higher tissue-permissiveness to SARS-CoV-2, or 
medRxiv preprint doi: https://doi.org/10.1101/2021.04.28.21255760; this version posted September 22, 2021. The copyright holder for this preprint (which was not certified by peer review) is the author/funder, who has granted medRxiv a license to display the preprint in All rights reserved. No reuse allowed without permission.

differences in interferon response at the site of entry, are most likely not responsible for pronounced disease. Other factors like involvement of activated immune cells and adaptive immunity (lacking in our model), higher infection susceptibility of the LRT and the role of additional comorbidities associated with smoking could constitute risk factors for pronounced COVID-19. Further investigations of these mechanisms are still needed.

The possibility of reversible smoking-induced alterations being restored in our reconstituted tissues presents the main limitation of our model. Using ALI cultures from primary human nonsmoker airway basal stem cells, Purkayastha A. et al recently showed that direct short-term exposure to cigarette smoke led to more severe SARS-CoV-2 disease due to the reduction of the immune response [10].

In conclusion, although no evidence of increased COVID-19 disease vulnerability in smokers was found, this work shows that, if such susceptibility exists, it would not involve early infection steps and is unlikely to be dependent on the response of the upper respiratory tract epithelium per se.

\section{Acknowledgments}

We thank Pascale Sattonnet-Roche for excellent technical support and Erik Boehm for English proof reading (Geneva Centre for Emerging Viral Diseases, Geneva University Hospitals, Geneva, Switzerland).

\section{Funding}

This work was supported by the Private HUG Foundation and by Pictet Charitable Foundation.

\section{Conflict of Interest declaration}

The authors declare that they have no known competing financial interests or personal relationships that could have appeared to influence the work reported in this paper. 
medRxiv preprint doi: https://doi.org/10.1101/2021.04.28.21255760; this version posted September 22, 2021. The copyright holder for this preprint (which was not certified by peer review) is the author/funder, who has granted medRxiv a license to display the preprint in All rights reserved. No reuse allowed without permission.

\section{References}

1. Rossato M, Russo L, Mazzocut S, Di Vincenzo A, Fioretto P, Vettor R. Current smoking is not associated with COVID-19. European Respiratory Journal 2020: 55(6).

2. Hopkinson NS, Rossi N, El-Sayed_Moustafa J, Laverty AA, Quint JK, Freidin M, Visconti A, Murray B, Modat M, Ourselin S. Current smoking and COVID-19 risk: results from a population symptom app in over 2.4 million people. Thorax 2021.

3. Lowe KE, Zein J, Hatipoglu U, Attaway A. Association of Smoking and Cumulative Pack-Year Exposure With COVID-19 Outcomes in the Cleveland Clinic COVID-19 Registry. JAMA Intern Med 2021. 4. Leung JM, Yang CX, Tam A, Shaipanich T, Hackett T-L, Singhera GK, Dorscheid DR, Sin DD. ACE2 expression in the small airway epithelia of smokers and COPD patients: implications for COVID-19. European Respiratory Journal 2020: 55(5).

5. Brake SJ, Barnsley K, Lu W, McAlinden KD, Eapen MS, Sohal SS. Smoking upregulates angiotensin-converting enzyme-2 receptor: a potential adhesion site for novel coronavirus SARS-CoV2 (Covid-19). Multidisciplinary Digital Publishing Institute, 2020.

6. Matusiak M, Schürch CM. Expression of SARS-CoV-2 entry receptors in the respiratory tract of healthy individuals, smokers and asthmatics. Respiratory research 2020: 21(1): 1-6.

7. Pizzorno A, Padey B, Julien T, Trouillet-Assant S, Traversier A, Errazuriz-Cerda E, Fouret J, Dubois J, Gaymard A, Lescure F-X. Characterization and treatment of SARS-CoV-2 in nasal and bronchial human airway epithelia. Cell Reports Medicine 2020: 1(4): 100059.

8. Essaidi-Laziosi M, Brito F, Benaoudia S, Royston L, Cagno V, Fernandes-Rocha M, Piuz I, Zdobnov E, Huang S, Constant S. Propagation of respiratory viruses in human airway epithelia reveals persistent virus-specific signatures. Journal of Allergy and Clinical Immunology 2018: 141(6): 20742084.

9. Kaur G, Lungarella G, Rahman I. SARS-CoV-2 COVID-19 susceptibility and lung inflammatory storm by smoking and vaping. J Inflamm (Lond) 2020: 17: 21.

10. Purkayastha A, Sen C, Garcia Jr G, Langerman J, Shia DW, Meneses LK, Vijayaraj P, Durra A, Koloff CR, Freund DR. Direct exposure to SARS-CoV-2 and cigarette smoke increases infection severity and alters the stem cell-derived airway repair response. Cell stem cell 2020: 27(6): 869-875. e864. 


\section{Figures}

A

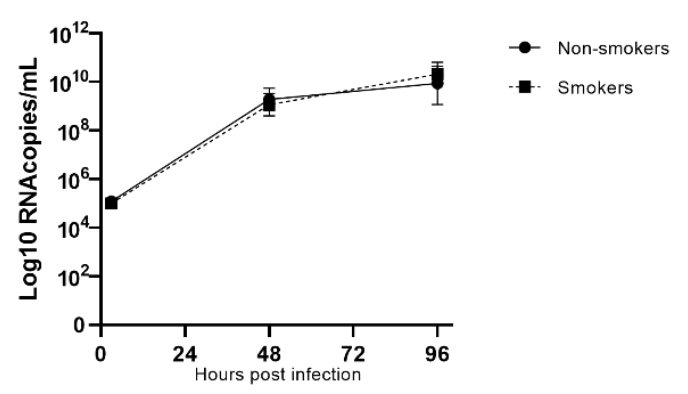

B

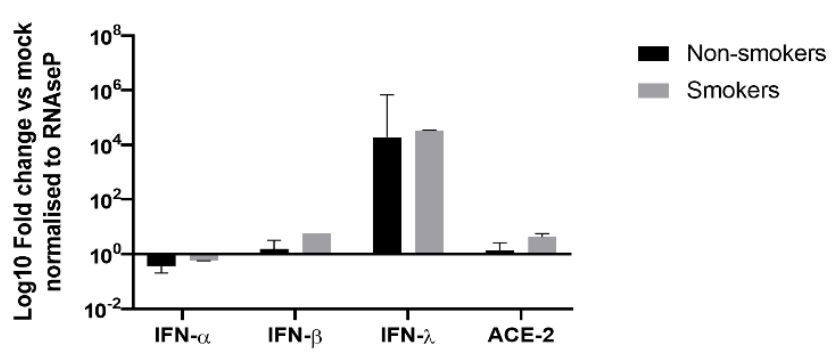

Figure1. SARS-CoV2 infections in 3D tissues from non-smoker versus smoker donors.

A. Virus replication. Virus production at the apical side of air-liquid interface culture $\left(37^{\circ} \mathrm{C}\right.$, $\mathrm{MOI}=0.01)$ of reconstituted human airway epithelia[8] derived from non-smoker $(\mathrm{N}=3)$ versus smoker $(\mathrm{N}=3)$ patients were compared at days 2 and 4 pi by quantitative real time PCR targeting the $\mathrm{E}$ gene. Four tissues have been tested for each donor. B. Host response induction in SARS-CoV2 infected tissues. The expression of IFNs $\alpha, \beta$ and $\lambda$ and ACE-2 receptor at day 4pi was semi-quantified by RT-qPCR on total RNA extracted from tissue lysates, normalized to housekeeping gene (RNAseP). Fold change of IFNs $\alpha, \beta$ and $\lambda$ and ACE-2 inductions in infections relative to non-infected tissues from non-smoker $(\mathrm{N}=3)$ versus smoker $(\mathrm{N}=3)$ patients were compared. Four tissues were tested for each donor. Statistical significance calculated using the two-way ANOVA showed non significant differences in viral replication and host response in tissues from the two groups. 


$$
1{ }^{-}
$$

